\title{
Integrated Weed Management for Large Scale Direct Seeding Hybrid Rice Cultivation at Irrigated Land in Indonesia
}

\author{
M. O. Adnyana ${ }^{1}$, I. G. M. Subiksa ${ }^{2 *}$, I. Putu Wardana, R. P. Ramadhan ${ }^{1}$, B. Priatmojo, O. D. \\ Purwanto ${ }^{1}$ \\ ${ }^{1}$ Indonesian Center for Food Crop Research and Development (ICFORD) Jl. Merdeka 147, Bogor 16111. \\ ${ }^{2}$ Indonesian Center for Agricultural Land Resource Research and Development (ICALRRD), Jl. Tentara Pelajar \\ No.12, Bogor 16111.
}

*Corresponding Author: I. G. M. Subiksa, Indonesian Center for Agricultural Land Resource Research and Development (ICALRRD), Jl.Tentara Pelajar No.12, Bogor 16111.

\begin{abstract}
Rice is cultivated in Indonesia in a very wide range of ecosystems but irrigated rice area remains dominating planted rice area. Transplanting is the major method of rice cultivation, however, transplanting is increasingly difficult due to shortage and high cost of labor. Direct seeding is gaining popularity and highly prospective among farmers in Indonesia. However, irrespective of the method of direct seeding rice establishment, weeds are the major impediment to rice production through their ability to compete for resources and their impact on rice productivity and product quality. The objective of this paper are: (1) to find out the best method to control weeds in large scale direct seeded hybrid rice with full mechanized rice cultivation and (2) to verify and evaluate the most productive and preferred hybrid rice variety, and (3) to analyze technically feasible and financially profitable of direct seeded rice. Demonstration farm (dem-farn) of integrated weed management in large scale hybrid rice cultivation was conducted at PT. Sang Hyang Seri on station irrigated rice area with plot size of about 12.6 ha. Two type irrigation techniques were applied such as continues submerge irrigation and intermittent irrigation in combination with herbicide application to control weed during the cropping season. Research ouputs showed that one of the most challenging biotic pressure in direct seeding hybrid rice at iirigated rice area is weed infestation. It is not only in direct seeding rice cultivation but also in transplanting practices. Weeds grow fast in alternately submerge and dry condition (intermittent irrigation), then compete with the rice crop. Financially, continues submerge and intermittent irrigation showed highly feasible compared with farmer's cultivation practices. On the other hand, added value of these two water management system was significantly incleases on-farm income.
\end{abstract}

\section{INTRODUCTION}

\subsection{Background}

Rice is cultivated in Indonesia in a very wide range of ecosystems from irrigated to rainfed, flood prone (shallow, mid-deep, and deep water), swampy land, to uplands, but irrigated land stills the largest planted rice area. Transplanting is the major method of rice cultivation in Indonesia. However, transplanting is becoming increasingly difficult due to shortage and high cost of labor, scarcity of water, and reduced on-farm profit. Thus, direct-seeding is gaining popularity and highly prospective among farmers of Indonesia as in other Asian countries. Direct-seeding constitutes both wet-seeding and dry-seeding, and it does away with the need for, nursery preparation, uprooting of seedlings and transplanting. In the rice agro-ecosystems ideal environment conditions are provided for optimal rice productivity are being exploited by the associated weeds. Irrespective of the method of rice establishment, weeds are a major impediment to rice production through their ability to compete for resources and their impact on product quality.

The amount of water allocation in plants depends on climate, soil type, the availability of water in the soil, the water requirement of the crop and farming practices (Susi et al. 2010). Rice grown under traditional practices in Asia including Indonesia requires between 700 and $1500 \mathrm{~mm}$ of water during a cropping season, depending on the soil texture (Tuong Bouman and Tuong 2001; Farooq et al. 2009; Talpur et al. 2011). The actual amount of water used by farmers for land preparation and during crop growth is much higher than the actual field requirementt. Water resources for agricultural production are becoming increasingly scarce and the development of new water resources involves very high costs. Thus, an improvement and increase in WUE are required for future food security. 
Proper weed management technologies if well adapted can result in an additional rice production. Thus weed management would continue to play a key role to meet the growing food demands of increasing population. As the weed problems are multi-pronged, a holistic multi-disciplinary integrated approach would be imperative. In this context, integrated weed management (IWM) may provide a more sustainable approach to rice production (Rao 2011).

Weed management must aim at reducing the weed population to a level at which weeds occurrence has no effect on farmers' economic and ecological interests. By using different appropriate management practices against weeds, farmers have more options for controlling weeds, thereby reducing the possibility of escapes and weed adaptation to any single weed management tactic. IWM is a science-based decision-making process that coordinates the use of environmental information, weed biology and ecology, and all available technologies to control weeds by the most economical means, while posing the least possible risk to people and the environment (Sanyal, 2008). The concept of IWM is not new. For example, the traditional practice of piddling soil to kill existing weeds and aid water retention, transplanting rice seedlings into standing water to achieve an optimum stand density, and maintaining standing water to suppress weeds, followed by one or several periods of manual weeding, is a well established example of integrated weed management (IWM) (Rao et al., 2007). Effective IWM combines preventive, cultural, mechanical and biological weed control methods in an effective, economical and ecological manner.

\subsection{Problem and Challenges}

Weeds are responsible for heavy rice yield losses, to the extent of complete crop loss under extreme conditions. Out of the losses due to various biotic stresses, weeds are known to account for nearly one third. Weed competition would be less severe under transplanting than those under direct-seeding (Singh et al., 2005; Savary et al., 2005; Rao and Nagamani, 2007; Rao et al., 2007). Uncontrolled weeds reduced the grain yield by $75.8 \%, 70.6 \%$ and $62.6 \%$ under dry-seeded rice (DSR), wet seeded rice (WSR) and transplanted rice (TPR) respectively (Singh et al., 2005). Experiments showed that yields were comparable across all establishment methods of rice when competition from weeds was removed. Thus, weed control is major prerequisite for improved rice productivity and production using different methods of rice establishment.

Conventional irrigation with continuous flooding has a low efficiency and another method of efficient water use such as alternative irrigation is needed in rice production (Tuong and Bhuiyan 1999). New technologies for saving water, such as alternate drying and wetting, raised beds and direct seeding are being tested in rice cultivation in South Asia (van der Hoek et al. 2001; Talpur et al. 2011). Water can be supplied to the plot of rice by either continuous or intermittent flooding (Susi et al. 2010). The first method is usually used when the water availability is sufficient for the requirement in the field. The second method is used when the water availability is insufficient for the irrigation requirements in the field and, in many cases, intermittent irrigation is necessary because of a lack of available of water. However, through well planned and executed intermittent irrigation, savings can be achieved, with an average irrigation water saving of 35\% compared with continuous irrigation (Bouman and Tuong 2001; Tabbal et al. 2002; Farooq et al. 2009; Susi et al. 2010).

Continuous irrigation needs high irrigation water requirement and tends to be excessive. Deficit of water are frequently happened because of long drought season and unpredictable rainfall. Competition also occurs between with not only among users in irrigation sector but also between sectors such as agriculture, raw water, and industry. Continuous irrigation with a water depth of $5-15 \mathrm{~cm}$ on the rice field is relatively easy to be operated, but consequently it requires higher irrigation water supply. Besides that, 5-15 cm water depth could keep the soil condition always wet and become an ideal condition for microorganism to produce higher methane emissions (Hidayah, et. al 2010). With continuous irrigation patterns, operation of the gates in the field would be easier. This operation mode requires relatively large volume of irrigation water because of higher percolation rate. In addition, such a condition becomes ideal for the formation of methane gas in large quantities.

The use of intermittent irrigation to create wet and dry soil conditions, use of rotary weeding to simultaneously control weeds and promote soil aeration and to enhance soil fertility by increasingly using organic fertilizers. This water management lead to higher yields and better rice quality because of the wider spacing and single planting that increases exposure to sunlight, air and nutrients. Due to 
intermittent watering, plants grow larger and establish effective root systems as compared to conventional methods. This in turn produces healthy plants with stronger stalks and more tillers leading to higher yields of good quality rice.

\subsection{Objective}

The objective of this paper are: (1) to find out the best method to control weeds in large scale direct seeded hybrid rice with full mechanized rice cultivation and (2) to verify and evaluate the most productive and preferred hybrid rice variety, and (3) to analyze technically feasible and financially profitable of direct seeded rice.

\section{Material AND Method}

\subsection{Demonstration Farm}

\subsubsection{Location and Topographic Survey}

Demonstration farm (dem-farm) of integrated weed management in large scale rice cultivation was conducted at PT. Sang Hyang Seri Farm in Sukamandi, Subang District West Java. Topographic survey was conducted to guide the land leveling activities in order to find out rice field as level as possible. The den-farm was carried out for hybrid rice cultivation at irrigated area and topographic survey showed that the rice field is relatively plat with plot size of about 12.6 ha.

\subsection{Material}

Three hybrid rice varieties were tested in this dem-farm that consisted of GH-21, SL-8 SHS, and Hipa-14 while Ciherang inbred rice variety is used as check. Total area of dem-farm is about 12.6 hectares. Those varieties are introduced by PT. SAS in collaboration with Guo Hao Seed Industry Ltd., PT. Sang Hyang Seri and Indonesia Center for Rice Research. Other inputs like fertilizer (NPK, organic fertilizer) are given based on crop need in accordance with soil tool kit analysis for P and K, and leaf color chart for urea in an integrated site specific nutrient management (SSNM). While water supply to rice crop is following intermittent irrigation technique based on crop growth stages (IRRI 2013) and continuous flooding system.

Yield lose is estimated average of $37 \%$ of rice crop to pests and diseases attack every year. In addition to good crop management, timely and accurate diagnosis can significantly reduce losses (IRRI 2013). Chemical control for pest and diseases is based on economic threshold unless there is endemic attack.

\subsection{Method}

The experiment has been conducted at irrigated low land rice area that belong to PT. Sang Hyang Seri in Sukamandi, Subang District, West Java in 2017 as one of the Government of Indonesia owned Company that engage in rice seed business. The experiment of integrated weed management has used dem-farm approach with 4 treatments namely: (1) Continues submerge without herbicide spraying, (2) continues submerge with herbicide spraying, (3) intermittent irrigation without herbicide spraying, and (4) intermittent irrigation with herbicide spraying, while existing farmer's cultivation practices has used as check for financial analysis.

\subsubsection{Direct Seeding Technique under Dry Soil Condition}

For the purpose of large scale and mechanized rice farming at irrigated rice area, multi-purpose direct seeder is attached to $80 \mathrm{HP}$ tractors. This multi-purpose direct seeder also equipped with ditcher that mainly exercised to dig the micro canal at every $2.5 \mathrm{~m}$ distance with the same direction to the seed rows (Adnyana et.,al 2017). The ditcher is installed at the middle of the 10 rows direct seeder to meet the requirement for micro canal in large scale rice farming. Seeder is attached to the tractor wheel in combination with hydraulic system to control drop of the seed per hill. Multi-purpose direct seeder was installed calibrated before used at the rice field.

Treated seed and NPK fertilizer are placed in its consecutive box. The fertilizer is dropped about $5 \mathrm{~cm}$ apart of seed at the same time during seeding. Direct seeding activities started including basal fertilizer application and micro canal at the middle for every $2.5 \mathrm{~m}$ distance. Soil covered seed rows and micro canal are well done at the rice field for better irrigation and drainage system. Micro canal with $20 \mathrm{~cm}$ width and $15-20 \mathrm{~cm}$ depth is helpful to irrigate and drainage large scale rice farming. 
Seeding, basal fertilizer application, seed coverage, ditching activities are 4 in 1 direct seeding equipments used under tractor movement that need between 4-5 hours per hectare .

\subsubsection{Water Management}

Intermittent irrigation is practiced in this experiment for the different periods of rice crop growing from pre-planting, early vegetative stage, productive stage, to the ripening stage (IRRI 2013). Water discharge to irrigate rice field of hybrid rice is between 0.6 to 1.2 liter per second based on the crop need and growth stages. Rehabilitation of quarterly canal is using backhoe for $1,450 \mathrm{~m}$ canal. On the other hand continuous submerge at $5-10 \mathrm{~cm}$ water height, once the water surface less than $5 \mathrm{~cm}$, water inflow was carried out for every 5-7 days after previous submerge.

Both irrigation and drainage canal are improved to secure the inlet and outlet water flows are functioning well. The formation of micro canal at every $2.5 \mathrm{~m}$ is carried out during seeding activities together with basal fertilizer application by the multi-purpose direct seeder. Micro canal with $20 \mathrm{~cm}$ wide and $20 \mathrm{~cm}$ dept established during the direct seeding activities to improve the water distribution during crop growing period.

In this research, the land is submerged continuously with water height of $5 \mathrm{~cm}$. To reach the water height from saturated soil conditions. For one hectare irrigated land in average, it takes about 3 days with an inlet discharge of $2.4 \mathrm{lt} / \mathrm{sec}$ for 24 hours inlet flow. However, if the discharge is sufficient (6 $1 \mathrm{t} / \mathrm{sec}$ ) the inlet flow just need only 24 hours or one day. The next day there is no water supply because it schedules water supply every 2 days. When there is no supply of irrigation water, the water height will decrease because of evapo-transpiration process of $3.6 \mathrm{~mm} /$ day and water loss through infiltration of $2.4 \mathrm{~mm} /$ day in average. After reaching the water height of $5 \mathrm{~cm}$, the discharge of water supply is only $0.7 \mathrm{lt} / \mathrm{sec}$ for 24 hours to maintain the water height of $5 \mathrm{~cm}$. Soil submerge is carried out continuously up to the rice crops at 75 days after seeding (DAS). Top dressing fertilizer application is done once the rice crops at 21-24 DAS and second top dressing fertilizer application at 42-45 DAS. Submerging irrigation water is stoped once rice crop reach 75 DAS to avoid lodging and speeding up grain maturity.

\subsubsection{Nutrient Management}

Nutrient management is following the concept of feed the crop need in an integrated site specific nutrient management (SSNM). SSNM provides scientific principles for optimally supplying rice with essential nutrients. It enables rice farmers to tailor nutrient management to the specific conditions of their field, and it provides a framework for nutrient best management practices for rice (IRRI 2013). Based on the soil analysis output at the dem-farm rice plot, basal fertilizer application of $350 \mathrm{~kg} / \mathrm{ha}$ compound NPK fertilizer is carried out at the same time with direct seeding activities under dry soil condition. Top dressing fertilizer with urea granule at $250 \mathrm{~kg} / \mathrm{ha}$ is carried out at 30 days after seeding (DAS). SSNM has potential for improving yields and nutrient efficiency in irrigated rice to close existing yield gaps. The major challenge for SSNM will be to retain the success of the approach while reducing the complexity of the technology as it is disseminated to farmers. The nature of the approach will need to be tailored to specific circumstances. In some areas, SSNM may be field or farm specific, but in many areas it is likely to be just region and season-specific (Dobermann et al., 2002; Pampolino et.al, 2007).

Before fertilizer application is carried out, soil surface was under saturated condition for more effective fertilizer and nutrient absorption by rice crops. Nutrient status of rice plant is monitored by using leaf color chart (LCC) especially Nitrogen during grain filling. Meanwhile, Soil Tool Kit is used to determine the status of Phosphorous (P) and Potassium (K) at the beginning of Best Management Practices (BMP) implementation. Before seeding, seed has been treated by insecticide (Carbosulfan) to control insect during germination and early vegetative growth.

\subsubsection{Integrated Pest Management}

Yield lose is estimated average of $37 \%$ of rice crop to pests and diseases attack every year. In addition to good crop management, timely and accurate diagnosis can significantly reduce losses (IRRI 2013). Major pest treated during the cropping season are stem borer, brown plant hopper and rats. Stem borer outbreak was occurred surrounding planted area, so that most of rice area did replanting. Control of this main insect was carried out by spreading Carbofuran and Fipronil. Rat population outbreak 
commonly occur on July - September, therefore trap barrier system (TBS) is used to trap rat. Plastic fence was also established at the border area of rice plot that equipped with rat trap to further protect rice plant from rat attack.

Seed treatment is also applied to control insect attack during the vegetative growth stage by using Carbosulfan to control insect during germination and early vegetative growth. Fipronil (Reagent) is applied to prevent stem borer attack during vegetative stage. Light trap is used to monitor the insect population dynamic as an early warning system approach. Anticipative chemical control can be applied in accordance with the early warning output.

\subsection{Financial Analysis}

Financial analysis is exercised to analyze the financial feasibility of large scale full mechanize rice farming at an area of about 12.6 hectares with direct seeding under dry soil condition and optimal application of technology components. Average on-farm hybrid and Inbred rice yield (ton/ha) wet grain is used as the main output with respect to agricultural inputs used per hectare. $\mathrm{R} / \mathrm{C}$ ratio is exercised to analyze the financial feasibility of this large mechanized rice farming with recorded cost component that include fixed cost and variable cost (Swastika 2004). The following formulas are used to analyze on-farm income and its financial feasibility (Muhammad et al. 2012 and Marimin 2014).

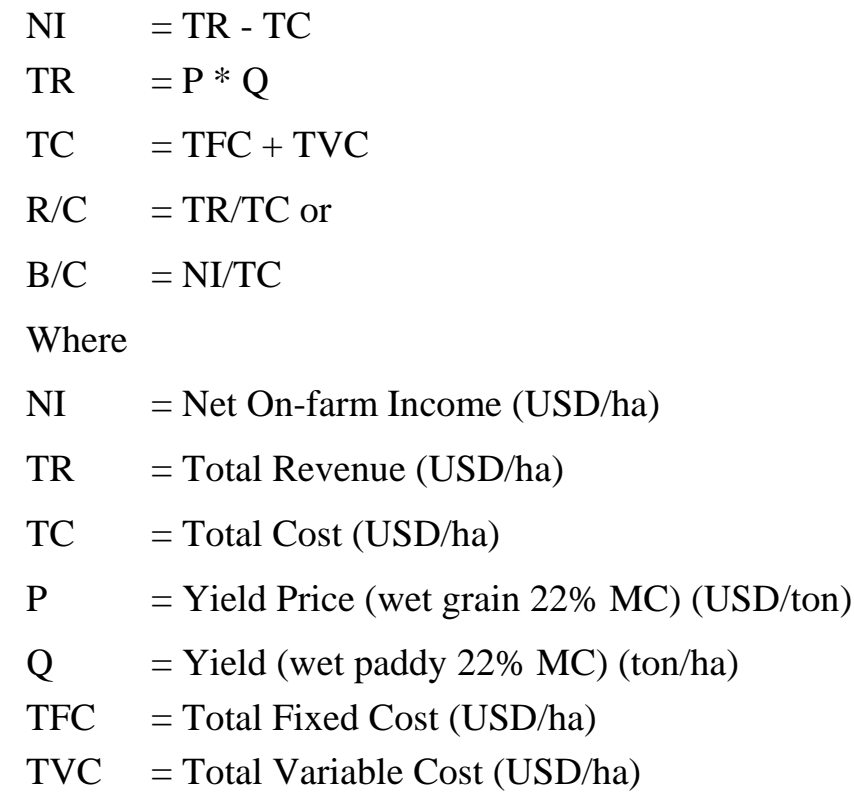

If $\mathrm{R} / \mathrm{C}>1.0$ or $\mathrm{B} / \mathrm{C}>0.0$ then large scale mechanized rice farming technology demonstrated in this dem-farm is financially feasible that can be developed in situ or outreaching to other irrigated rice area. On the other hand, if $\mathrm{R} / \mathrm{C}<1.0$ or $\mathrm{B} / \mathrm{C}<0.0$, this indicated that this technology is not feasible to be developed further. On the other hand, in order to measure the additional benefit that gained by large scale, mechanized rice farming with respect to the farmer practices, MBCR (marginal benefit cost ratio) then exercised as follow:

MBCR $=\frac{\text { Total Gains }}{\text { Total Losses }}$

Where:

Total Gains $=$ Total additional income gained from introduced technology

Total Losses $=$ Total additional cost expended due to application of introduced technology .

If MBCR > 1, the introduced technology (introduced hybrid rice varieties) is financially feasible to be scaling up in situ or out reaching to newly open area. Otherwise, if MBCR $\leq 1$ then hybrid rice varieties did not feasible or the introduced technology just the same with farmer practices or even worst.

Sensitivity Analysis aims to see the sensitivity or sensitivity of Jarwo Super rice farming if there is a change in cost calculation (Sahara 2007). In this analysis, sensitivity analysis is determined at the 
level of price changes with various models or assumptions either separately or simultaneously which are close to field reality with scenarios:

1. Production costs increase by $20 \%$ including the cost of production facilities, labor and other costs, while the production and price of unhusked rice.

2. Production fell by $20 \%$, but fixed grain prices and production costs remained.

3. Production decreases by $20 \%$ and production costs increase by $20 \%$ which includes the cost of production facilities, labor and other costs.

\section{RESULTS AND DISCUSSION}

\subsection{Weeds Growth Among Treatments}

Type of weeds and population under different irrigation technique and chemical control are presented in Table 1. Three types of weed were identified during the demonstration farm of integrated weed management, namely broad leafs, sedges, and grasses. Under continues submerge irrigation without herbicide application outputs showed that number of weeds per sqm is 54,154 , and 8 weeds for broad leafs, sedges, and grasses in average respectively. However, continues submerge in combination with herbicide application was able to depress near to zero population.

Meanwhile, under intermittent irrigation but witout herbicide application, population of each type of weed were significantly compared with continues submerge irrigation such as broad leafts, sedges, and grasses with population per sqm at 422, 338, and 16 weeds in average respectively. Once herbicide has been applied at trghe sam irrigation technique the population significantly drop to only 1.5 in avarwerage for broad leafs type and none for sedges and grasses.

These research finding showed that the application of herbicide eather under continues submerge irrigation or intermittent irrigation technique was significantly control three weeds type infestation under direct seeding technique of hibrid rice at irrigated rice field. However, the continues iirigation was performed better to control weeds compared to intermittent irrigation technique (Table 1).

In line with the type of weed and population, different irrigation techniques also affect the weed biomass. The highest biomass either wet or dried biomass at continues submerge irrigation without herbicide application was identified on sedges weed type at about $2,223.2 \mathrm{gr} / \mathrm{m}^{2}$ wet and $255 \mathrm{gr} / \mathrm{m}^{2}$ dried biomass. Meanwhile, the highest weed biomass at continues submerge irrigation technique also without hercide application is sedges weed type with wet biomass at about $203.5 \mathrm{gr} / \mathrm{m}^{2}$ and 20.7 $\mathrm{gr} / \mathrm{m}^{2}$ dried biomass (Table 2). This research outputs showed that even though without herbicide application, continues submerge irrigation technique in hybrid rice cultivation by using direct seeding technique under dry soil condition was able to reduce the weed biomass in line with weed population. The weed biomass will be very much lower once the herbicide was applied during the cropping season.

Table1.Type of weed and population under irrigation technique and chemical control

\begin{tabular}{|c|c|c|c|c|c|}
\hline \multirow{2}{*}{ No. } & \multirow{2}{*}{ Treatments } & \multicolumn{3}{|c|}{ Number of Weeds per sqm } \\
\cline { 4 - 6 } & & Rep. & Broad leafs & Sedges & Grasses \\
\hline I & Continues Submerge & & & & \\
\hline & No Herbicide & 1 & 80 & 244 & 8 \\
\hline & & 2 & 28 & 64 & 8 \\
\hline & Average & 1 & 54 & 154 & 8 \\
\hline & Herbicide & 2 & 0 & 0 & 0 \\
\hline & Average & & 0.5 & 0 & 0 \\
\hline & Intermittent Irrigation & 1 & 720 & 416 & 0 \\
\hline II & No Herbicide & 2 & 124 & 260 & 16 \\
\hline & Average & & 422 & 338 & 16 \\
\hline & Herbicide & 2 & 0 & 0 & 0 \\
\hline & & & 3 & 0 & 0 \\
\hline & Average & & & 0 & 0 \\
\hline & & & & \\
\hline
\end{tabular}


On the other hand, the effect on irrigation technique in combination with herbicide application to control weed in relation to plant growth and crop performance are presented in Table 3. In general, irrigation technique in combination with herbicide application showed better effect to plant height with $118 \mathrm{~cm}$ for continues submerge and $121 \mathrm{~cm}$ for intermittent irrigation, while without herbicide application the plant height is about $113 \mathrm{~cm}$ and $110 \mathrm{~cm}$ for contonues submerge as well as intermittent irrigation respectively. This research outputs indicated that intermittent irrigation can increase plant height compared to the continues submerge irrigation technique especially under herbicide application but not without hercides.

Table2. Weeds biomass based on type of water management.

\begin{tabular}{|c|c|c|c|}
\hline \multirow{2}{*}{ No. } & Weeds Type & \multicolumn{2}{|c|}{ Biomass $\left(\mathrm{g} / \mathrm{m}^{2}\right)$} \\
\cline { 3 - 4 } & & Wet Biomass & Dry Biomass \\
\hline I & Continues Submerge/No Herbicide & & 6.92 \\
\hline & Broad leafs & 65.5 & 20.7 \\
\hline & Sedges & 203.5 & 3.3 \\
\hline & Grasses & 20.5 & \\
\hline II & Intermittent Irrigation/No Herbicide & & 255 \\
\hline & Broad leafs & $2,223.2$ & 67.8 \\
\hline & Sedges & 573.8 & 26.7 \\
\hline & Grasses & 152.2 & \\
\hline
\end{tabular}

Table3. Plant height performance among ttreatment

\begin{tabular}{|c|c|c|c|c|c|}
\hline \multirow{2}{*}{ Water Mgt } & \multirow{2}{*}{ Herbicide } & \multicolumn{4}{|c|}{ Plant Height (cm) } \\
\cline { 3 - 6 } & & I & II & III & Avg. \\
\hline Continues Submerge & W/O Herbicide & 115 & 114 & 110 & 113 \\
\hline & With Herbicide & 118 & 121 & 116 & 118 \\
\hline & & & & & \\
\hline Intermittent Irrigation & W/O Herbicide & 110 & 110 & 109 & 110 \\
\hline & With Herbicide & 123 & 124 & 115 & 121 \\
\hline
\end{tabular}

Beside of weed, pest and diseases are also part of biotic pressure to the rice crop at irrigated rice area. Some of dominand pest and diseases identified during the crop season are rat, golden snail, mole cricket, stem borer, brown plant hopper, BLB, and rice bug. Rat attact was controled by using poisoned bait and fumigation even rice was protected by using plastic fence since the rat attact was in high intencity along the crop season.

Goden snail, mole cricket, and stem borer were controled using molucide and insecticide at 1-20 das, 1-15 das, and 14-30 das respectively, while brown plant hopper was controled by using sustemic insecticide at 29 das (Table 4). Fungicide (Score) and insecticide ware applied to control BLB and rice bug. The use of insecticides and fungicides were determines base on location specific environment and its availability at local agri-inputs shop in Sukamandi, Subang District. Basically, pest and diseases attact were able controled by insecticide and fungicide on the right time and place.

One of the yield components that significantly determine the crop yield is number of productive panicles per hold hild. Two different irrigation technique in combination with herbicide application on large scale hybrid rice cultivation at irrigated rice field have significatly increased the number or rice panicle per hill. For example, continues submerge irrigation without herbicide application produce 16 panicles per hill and increased to 20.33 panicle per hill once herbicide was applied. On the other hand, number of productive panicles is only 6.33 per hill in intermittent irrigation without herbicide application and increased to 19.33 panicles per hill with herbicide application (Table 5).

Table4. Pest and diseases during crop season

\begin{tabular}{|c|c|c|c|}
\hline No. & Kind of Pest and Diseases observed & Infestation time & Control Measures \\
\hline 1. & Rat & Along season & Fumigation, Poisoned bait, Plastic fence \\
\hline 2. & Golden Snail & $1-20$ das & Molucide \\
\hline 3. & Mole Cricket (Gryllotalpa sp.) & $1-15$ das & Insecticide \\
\hline 4. & Stem borer & $14-30$ das & Insecticide \\
\hline 5. & Brown plant hopper & 29 das & Systemic Insecticide \\
\hline 6. & BLB & 55 das & Fungicide (Score) \\
\hline 7. & Rice bug & 70 das & Insecticide \\
\hline
\end{tabular}

Note: das = days after seeding 
Integrated Weed Management for Large Scale Direct Seeding Hybrid Rice Cultivation at Irrigated Land in Indonesia

Table5. Number of panicles among treatments

\begin{tabular}{|c|c|c|c|c|c|}
\hline \multirow{2}{*}{ Water Mgt } & \multirow{2}{*}{ Herbicide } & \multicolumn{4}{|c|}{ Number of Panicles } \\
\cline { 3 - 6 } & & I & II & III & Avg. \\
\hline Continuous Submerge & W/O Herb. & 18 & 16 & 14 & 16.00 \\
\hline & With Herb. & 23 & 15 & 23 & 20.33 \\
\hline & & & & & \\
\hline Intermittent Irrigation & W/O Herb. & 3 & 7 & 9 & 6.33 \\
\hline & With Herb. & 17 & 20 & 21 & 19.33 \\
\hline
\end{tabular}

The direct seeded rice applied on hybrid rice cultivation at irrigated rice field has faced alot of challenges either biotic and abiotic pressure along the cropping season at about 110 days. Witout proper irrigation techniques in combination with right dosage and type of pesticides, yield loss will be very high especially at intermittent irrigation without herbicide application with yield only 1.63 ton/ha. Once combined with herbicide the rice yield cand be safed up to 9.28 ton/ha in average. On the other hand, even though without herbicide application, continues submerge irrigation technique has able to produce 6.07 ton/ha and yield was significantly increase up to to 9.78 ton/ha in average once the herbicide was applied. (Table 6). This indicated that what ever irrigation techniques applied on direct seeding rice cultivation, herbicide seem to be required to safe and reduce rice yield loss for rice farming at irrigated area.

Table6. Hybrid rice yield among treatments

\begin{tabular}{|c|c|c|c|c|}
\hline \multirow{2}{*}{ Treatment } & \multicolumn{3}{|c|}{ Yield 26\% MC (Ton/ha) } & Average \\
\cline { 2 - 5 } & I & II & III & 6.07 \\
\hline Continuous Submerge & & & 6.04 & 9.78 \\
\hline No. Herbicide & 6.76 & 5.41 & 10.20 & \\
\hline Herbicide Spraying & 9.89 & 9.26 & & 1.63 \\
\hline Intermittent Irrigation & & & 2.50 & 9.28 \\
\hline No. Herbicide & 0.83 & 1.56 & 9.89 & \\
\hline Herbicide Spraying & 9.21 & 8.74 & & \\
\hline
\end{tabular}

\subsection{Financial Analysis Outputs}

\subsubsection{Financial Feasibility Level}

Cost structure of technology validation and verification of hybrid rice farming consisted of four main components such as agricultural inputs, labor and operator, and other (land rent and water management cost). The total cost per hectare is about USD 1,156.46 with yield 8.86 ton/ha or about USD 130.52/ton wet paddy with moisture content $(\mathrm{MC}=22 \%)$. About $50.0 \%$ of total production cost is allocated for agricultural input (USD 578.23) and 27.4\% (USD 316.56) for hard labor cost and about 22.6\% (USD 261.67) for fixed cost that consisted of land rent, land leveling and irrigation fee. Total gross income is USD 2,584.20/ha with net income about USD 1,427.74/ha, while net income of farmer's rice cultivation practices is about USD 805.33/ha with yield 5.65 ton/ha (Table 7).

Table7. Financial feasibility analysis

\begin{tabular}{|c|c|c|c|c|c|c|c|}
\hline \multirow[t]{2}{*}{ No } & \multirow[t]{2}{*}{ Description } & \multirow[t]{2}{*}{$\begin{array}{l}\text { Unit price } \\
\text { (USD/unit) }\end{array}$} & \multicolumn{2}{|c|}{$\begin{array}{c}\text { Continuous } \\
\text { Submerge Irrigation } \\
\text { System }\end{array}$} & \multicolumn{2}{|c|}{$\begin{array}{c}\text { Intermittent } \\
\text { Irrigation } \\
\text { System } \\
\end{array}$} & \multirow{2}{*}{$\begin{array}{c}\text { Farmer } \\
\text { Practice } \\
\text { s } \\
\text { (USD/ha } \\
\text { ) }\end{array}$} \\
\hline & & & Amount & $\begin{array}{c}\text { Value } \\
\text { (USD/ha) }\end{array}$ & $\begin{array}{c}\text { Amou } \\
\text { nt }\end{array}$ & $\begin{array}{c}\text { Value } \\
\text { (USD/ha) }\end{array}$ & \\
\hline \multicolumn{8}{|c|}{ I. Expenses } \\
\hline \multicolumn{8}{|c|}{ A. Agricultural Inputs } \\
\hline 1 & Seed $(\mathrm{kg} / \mathrm{ha})$ & 5.00 & 30.00 & 150.00 & 30.00 & 150.00 & 15.00 \\
\hline \multirow[t]{2}{*}{2} & Fertilizer & & & & & & \\
\hline & Sub Total (USD/ha) & & & 253.00 & & 253.00 & 207.00 \\
\hline \multirow[t]{2}{*}{3} & Herbicide & & & & & & \\
\hline & Sub Total (USD/ha) & & & 9.76 & & 15.56 & 3.96 \\
\hline \multirow[t]{2}{*}{4} & Pesticide & & & & & & \\
\hline & Sub Total (USD/ha) & & & 56.74 & & 56.74 & 40.07 \\
\hline & B. Labor & & & 316.06 & & 328.57 & 399.91 \\
\hline & C. Fixed Cost & & & & & & \\
\hline
\end{tabular}


Integrated Weed Management for Large Scale Direct Seeding Hybrid Rice Cultivation at Irrigated Land in Indonesia

\begin{tabular}{|c|c|l|l|c|c|c|c|}
\hline & Sub Total & & & 271.67 & & 271.67 & 176.67 \\
\hline \multicolumn{2}{|c|}{ Total Cost } & & & 1057.23 & & 1075.54 & 842.61 \\
\hline \multicolumn{2}{|c|}{ II. On-Farm Income } & & & & & & \\
\hline 1 & Yield (wet grain (ton/ha) & & 9.78 & & 9.28 & & 5.56 \\
\hline 2 & Price (USD/ton wet grain) & 275.86 & & & & & \\
\hline 3 & Gross Income (USD/ha) & & & 2697.91 & & 2559.98 & 1533.78 \\
\hline 4 & Net Income (USD/ha) & & & 1640.69 & & 1484.45 & 691.17 \\
\hline & R/C Ratio & & & 2.55 & & 2.38 & 1.82 \\
\hline & B/C Ratio & & & 1.55 & & 1.38 & 0.82 \\
\hline & MBCR & & & & & & \\
\hline & a. CSI vs FP & & & 5.42 & & & \\
\hline & b. IIS vs FP & & & & & 4.41 & \\
\hline
\end{tabular}

The financial feasibility indicators showed that the large scale full mechanize hybrid rice farming is highly feasible with $\mathrm{RC}$ ratio 2.23 and $\mathrm{BC}$ ratio 1.23 . In other words, every USD 1,000 operational cost will provide gross return and net return about USD 2,230 and USD 1,230 respectively. In addition, MBCR was about 2.98 that indicated for every USD 1.0 additional cost due to adoption of large scale mechanized rice farming will generate additional gross income of about USD 2.98 or USD 1.98 which is highly feasible compared with existing farmer practices that use to grow inbred rice varieties such us Ciherang.

\subsubsection{Financial Sensitivity Analysis}

Sensitivity analysis was carried out base on three scenarios suca as : (1) production costs increase by $20 \%$, while the production and price of unhusked rice remain the same, (2) production fell by $20 \%$, but grain prices and production costs did not change, and (3) production decreases by $20 \%$ and production costs increase by $20 \%$, while price of unhusked rice remain the same.

Sensitivity analysis output based on scenario- 1 or costs increases by $20 \%$ showed that B/C ratio of continuous submerge irrigation system as a part of water management to control weed declined from 1.55 to 1.13 and MBCR with respect to farmer's practices also declined from 5.42 to 4.52. Meanwhile $\mathrm{B} / \mathrm{C}$ ratio of intermittent irrigation system declined from 1.38 to 0.98 and MBCR declined to 3.67 from 4.41 (Appendex 2).

Meanwhile, sensitivity analysis based on scenario- 2 or production fell by $20 \%$ showed that $\mathrm{B} / \mathrm{C}$ ratio of continuous submerge and intermittent irrigation system for weed control was significantly declined to 1.04 and 0.90 from 5.42 and 4.52 respectively. MBCR of these two water management systems with respect to farmer's practices has also declined to 4.34 and 3.52 from 5.42 and 4.52 respectively (Appendix 3).

The most extreme sesnsitivity analysis scenario is once the production decreases by $20 \%$ and production costs increases by $20 \%$ which includes the cost of production facilities, labor and other costs. The senitivity analysis output showed that $\mathrm{B} / \mathrm{C}$ ratio of continuous submerge as well as intermittent irrigation system to control weed has significantly declined to the lowest 0.70 and 0.59 respectively, while MBCR with respect to farmer's cultivation practices declined from 5.42 to 2.19 for continuous submergen practices and from 4.41 to 1.83 for intermittent irrigation system (Appendix 4).

\section{CONCLUSiON}

Weeds infestation has become one of the most constraints in rice farming, not only in direct seeding but also in transplanting practices. Weeds grow fast in alternately submerge and dry condition (intermittent irrigation), then compete with the rice crop. Weeds infestation could suppress by applying continue submerge irrigation. Practicing intermittent irrigation in rice farming should be followed by intensive weeds control with herbicde application. There is no significant different grain yield between continues submerge and intermittent irrigation, along weeds infestation once herbicide was effectively applied.

Financially, continues submerge and intermittent irrigation showed highly feasible compared with farmer's cultivation practices. On the other hand, added value of of these two water management system was significantly incleases on-farm income of rice farming at irrigated area even though cost was also increased compared with farmer's cultivation practices. On the other hand the the most extreme sesnsitivity analysis impact is that, the production decreases by $20 \%$ and production costs 
increases by $20 \%$ that possible to be affected by biotic and abiotic pressure including weed infestation.

\section{REFERENCES}

[1] IRRI. 2013. Land Preparation. Best Management Practices, Rice Knowledge Bank. International Rice Research Institute, Los Banos Philippines.

[2] IRRI. 2013. Water Management. Introduction to Sound Water Management Rice. Knowledge Bank. International Rice Research Institute. Los Banos, Philippines. http://www.knowledgebank.irri.org/rkb/2sound-water-management.html

[3] IRRI 2013. How to manage rice pest and diseases. Rice Knowledge Bank. International Rice Research Institute (IRRI), Los Banos, Philippines.

[4] Stephen. M. 2010. Integrated weed management (IWM): will it reduce herbicide use? Commun Agric Appl Biol Sci. 2010; 75(2):9-17. United Kingdom.

[5] Rao, A.N. 2011. Integrated Weed Management in Rice in India. Rice Knowledge Management Portal. Directorate of Rice Research. Rajendranagar, Hyderabad India.

[6] Anbhazhagan, R. and Kathiresan, R. M. 2008. Weed management in integrated rice+fish+poultry farming system. Green Farming. 2, 50-52.

[7] Angiras, N.N. and V. Sharma. 1998. Integrated weed management studies in direct seeded upland rice (Oryza sativa). Indian J. Weed Sci. 30, 32-35.

[8] Arokiaraj, A. Chandrasekaran, B. Chinnaswami. and K. N. Sankaran, S. 1989. Effect of critical period of crop weed competition in transplanted rice. Oryza. 26, 201-203.

[9] Arya, M.P.S., Singha, R.V. and Singh, G. 1991. Crop Weed Competition Studies in Rainfed Rice With Special Reference to Oxalis latifolia. Indian J. Weed Sci. 23, 40-45.

[10] Aulakh, C.S. and S. P. Mehra. 2006. Integrated management of red sprangletop [Leptochloa chinensis (L.) Nees] in transplanted rice. Indian J. Weed Sci. 38, 225-229.

[11] Balasubramanian, R. and Veerabadran, V. 1998. Herbicidal weed management in lowland rice (Oryza sativa) nursery. Indian J. Agronomy. 43, 437-440.

[12] Bouman BAM, Tuong TP. 2001. Field water management to save water and increase its productivity in irrigated lowland rice. Agr Water Manage. 49(1):11-30.

[13] Brar,L. S.,Kolar, J. S. and L.S. Brar. 1995. Critical period of competition between Caesulia axillaris Roxb. and transplanted rice. Indian J. Weed Sci. 27, 154-157.

[14] Chitale, S., Pandey, N. and Urkurkar, J. S. 2007. Effect of planting method, tillage and weed management on productivity and physico-chemical properties of rice (Oryza sativa)-wheat (Triticum aestivum) cropping system. Indian J. Agronomy. 52, 283-288.

[15] Dhammu, H. S. and Sandhu, K. S. 2002. Critical period of Cyperus iria L. competition in transplanted rice. Proc. 13th Australian Weeds Conference: weeds "threats now and forever?", Sheraton Perth Hotel, Perth, Western Australia, 8-13 September 2002: Pp. 79-82.

[16] Farooq M, Kobayashi N, Wahid A, Ito O, Basra SMA. 2009. Strategies for producing morerice with less water. Adv Agron. 101:351-388.

[17] Rao, A.N. 2014. Integrated weed management in India. International Rice Research Institute (IRRI), Philippines.

[18] Susi HSD, Marasi AA, Soekrasno DJ. 2010. Intermittent irrigation in system of riceintensification potential as an adaptation and mitigation option of negative impacts of rice cultivation in irrigated paddy field. Available from: www.rid.go.th/. . ./2.10-Susi_H-Dewi_AA-Marasi_DJ-Soekrasno.pdf.

[19] Tabbal DF, Bouman BAM, Bhuiyan SI, Sibayan EB, Sattar MA. 2002. On-farm strategies for reducing water input in irrigated rice; case studies in the Philippines. Agr Water Manage. 56:93-112.

[20] Talpur MA, Changying J, Junejo SA, Guangzhao T, Tagar AA, Chandio FA. 2011. A review on the enhancement of rice production in paddy field with minimum input of water. Afr JAgr Res. 6:6776-6779.

[21] Tuong TP, Bouman, BAM. 2003. Rice production in water-scarce environments. In: KijneJW, Barker R, Molden D, editors. Water productivity in agriculture: limits and opportunities for improvement. The comprehensive assessment of water management in agriculture. Series 1. Wallingford (UK): CAB International. p. 13-42.

[22] Van der Hoek W, Sakthivadivel R, Renshaw M, Silver JB, Birley MH, Konradsen F. 2001. Alternate wet/dry irrigation in rice cultivation: a practical way to save water and controlmalaria and Japanese encephalitis? Research report 47. Colombo (Sri Lanka): Interna-tional Water Management Institute.

[23] Tuong TP, Bhuiyan SI. 1999. Increasing water-use efficiency in rice production: farm-levelperspectives. Agr Water Manage. 40:117-122. 
Integrated Weed Management for Large Scale Direct Seeding Hybrid Rice Cultivation at Irrigated Land in Indonesia

Appendix1. Financial analysis output of large scale full mechanized rice farming, 2017.

\begin{tabular}{|c|c|c|c|c|c|c|c|}
\hline \multirow[t]{2}{*}{ No. } & \multirow[t]{2}{*}{ Description } & \multirow[t]{2}{*}{$\begin{array}{c}\text { Unit price } \\
\text { (USD/unit) }\end{array}$} & \multicolumn{2}{|c|}{$\begin{array}{c}\text { Continuous } \\
\text { Submerge } \\
\text { Irrigation System }\end{array}$} & \multicolumn{2}{|c|}{$\begin{array}{l}\text { Intermittent } \\
\text { Irrigation } \\
\text { System }\end{array}$} & \multirow[t]{2}{*}{$\begin{array}{c}\text { Farmer } \\
\text { Practices } \\
\text { (USD/ha) }\end{array}$} \\
\hline & & & Amount & $\begin{array}{c}\text { Value } \\
\text { (USD/ha) }\end{array}$ & Amount & $\begin{array}{c}\text { Value } \\
\text { (USD/ha) }\end{array}$ & \\
\hline \multicolumn{8}{|c|}{ I. Expenses } \\
\hline \multicolumn{8}{|c|}{ A. Agricultural Inputs } \\
\hline 1 & Seed (kg/ha) & 5.00 & 30.00 & 150.00 & 30.00 & 150.00 & 15.00 \\
\hline 2 & Fertilizer & & & & & & \\
\hline & Urea (kg/ha) & 0.26 & 250.00 & 65.00 & 250.00 & 65.00 & 65.00 \\
\hline & NPK (kg/ha) & 0.46 & 300.00 & 138.00 & 300.00 & 138.00 & 92.00 \\
\hline & $\mathrm{KCl}(\mathrm{kg} / \mathrm{ha})$ & 0.50 & 100.00 & 50.00 & 100.00 & 50.00 & 50.00 \\
\hline & Sub Total (USD/ha) & & & 253.00 & & 253.00 & 207.00 \\
\hline \multirow[t]{4}{*}{3} & Herbicide & & & & & & \\
\hline & Logran (sachet/ha) & 0.58 & 10.00 & 5.80 & 20.00 & 11.60 & - \\
\hline & Ricestar (lt/ha) & 7.92 & 0.50 & 3.96 & 0.50 & 3.96 & 3.96 \\
\hline & Sub Total (USD/ha) & & & 9.76 & & 15.56 & 3.96 \\
\hline \multirow[t]{8}{*}{4} & Pesticide & & & & & & \\
\hline & Reagen (lt/ha) & 20.83 & 1.00 & 20.83 & 1.00 & 20.83 & 20.83 \\
\hline & Demenhipo (lt/ha) & 6.67 & 1.00 & 6.67 & 1.00 & 6.67 & - \\
\hline & Nativo (pack/ha) & 5.00 & 1.00 & 5.00 & 1.00 & 5.00 & - \\
\hline & $\begin{array}{c}\text { Chemical adhesive } \\
\text { (lt/ha) }\end{array}$ & 3.33 & 1.50 & 5.00 & 1.50 & 5.00 & - \\
\hline & Marshall (sachet/ha) & 0.58 & 3.00 & 1.74 & 3.00 & 1.74 & 1.74 \\
\hline & Furadan (kg/ha) & 1.25 & 14.00 & 17.50 & 14.00 & 17.50 & 17.50 \\
\hline & Sub Total (USD/ha) & & & & & & \\
\hline \multicolumn{2}{|r|}{ B. Labor } & & & & & & \\
\hline 1 & $\begin{array}{c}\text { Tractor for land } \\
\text { preparation (USD/ha) }\end{array}$ & 125.00 & 1.00 & 125.00 & 1.00 & 125.00 & 125.00 \\
\hline 2 & Direct seeding & 45.97 & 1.00 & 45.97 & 1.00 & 45.97 & 60.61 \\
\hline 3 & Spraying (md/ha) & 4.17 & 5.00 & 20.85 & 7.00 & 29.19 & 33.03 \\
\hline 4 & Rat fumigation (md/ha) & 4.17 & 2.00 & 8.34 & 3.00 & 12.51 & 8.34 \\
\hline 5 & $\begin{array}{l}\text { Top dressing fertilizer } \\
\text { application (md/ha) }\end{array}$ & 4.17 & 2.00 & 8.34 & 2.00 & 8.34 & 8.34 \\
\hline 6 & $\begin{array}{c}\text { Irrigation canal } \\
\text { maintenance (backhoe) }\end{array}$ & 6.11 & 5.00 & 30.55 & 5.00 & 30.55 & - \\
\hline 7 & $\begin{array}{c}\text { Harvest with Combine } \\
\text { Harvester }\end{array}$ & 35.31 & 1.00 & 35.31 & 1.00 & 35.31 & 73.68 \\
\hline 8 & $\begin{array}{l}\text { Pest and diseases } \\
\text { monitoring (md/ha) }\end{array}$ & 4.17 & 10.00 & 41.70 & 10.00 & 41.70 & - \\
\hline 4 & Weeding (3 times) & & & & & 90.91 & \\
\hline & Sub Total & & & 316.06 & & 328.57 & 399.91 \\
\hline \multicolumn{2}{|r|}{ C. Fixed Cost } & & & & & & \\
\hline 1 & Land rent & 166.67 & 1.00 & 166.67 & 1.00 & 166.67 & 166.67 \\
\hline 2 & GPS guided land leveling & 85.00 & 1.00 & 85.00 & 1.00 & 85.00 & \\
\hline \multirow[t]{2}{*}{3} & Irrigation (water mgt) & 10.00 & 3.00 & 20.00 & 2.00 & 20.00 & 10.00 \\
\hline & Sub Total & & & 271.67 & & 271.67 & 176.67 \\
\hline \multicolumn{2}{|r|}{ Total Cost } & & & 1057.23 & & 1075.54 & 842.61 \\
\hline \multicolumn{2}{|r|}{ II. On-Farm Income } & & & & & & \\
\hline 1 & $\begin{array}{l}\text { Yield (wet grain, } 22 \% \\
\text { MC) (ton/ha) }\end{array}$ & & 9.78 & & 9.28 & & 5.56 \\
\hline 2 & Price (USD/ton wet grain) & 275.86 & & & & & \\
\hline 3 & Gross Income (USD/ha) & & & 2697.91 & & 2559.98 & 1533.78 \\
\hline \multirow[t]{5}{*}{4} & Net Income (USD/ha) & & & 1640.69 & & 1484.45 & 691.17 \\
\hline & R/C Ratio & & & 2.55 & & 2.38 & 1.82 \\
\hline & B/C Ratio & & & 1.55 & & 1.38 & 0.82 \\
\hline & MBCR & & & & & & \\
\hline & Continues & & & 5.42 & & & \\
\hline
\end{tabular}


Integrated Weed Management for Large Scale Direct Seeding Hybrid Rice Cultivation at Irrigated Land in Indonesia

\begin{tabular}{|l|l|c|l|l|l|l|l|l|}
\hline & & $\begin{array}{c}\text { submerge/farmer } \\
\text { practices }\end{array}$ & & & & & & \\
\hline & b. & $\begin{array}{c}\text { Intermittent/Farmer } \\
\text { practices }\end{array}$ & & & & & 4.41 & \\
\hline
\end{tabular}

Appendix2. Sensitivity analysis output of large scale full mechanized rice farming, 2017. Production costs increase by $20 \%$ including the cost of production facilities, labor and other costs, while the production and price of unhusked rice remain the same.

\begin{tabular}{|c|c|c|c|c|c|c|c|}
\hline \multirow[t]{2}{*}{ No } & \multirow[t]{2}{*}{ Description } & \multirow[t]{2}{*}{$\begin{array}{l}\text { Unit price } \\
\text { (USD/unit) }\end{array}$} & \multicolumn{2}{|c|}{$\begin{array}{l}\text { Continuous Submerge } \\
\text { Irrigation System }\end{array}$} & \multicolumn{2}{|c|}{$\begin{array}{c}\text { Intermittent Irrigation } \\
\text { System }\end{array}$} & \multirow{2}{*}{$\begin{array}{l}\text { Farmer } \\
\text { Practices } \\
\text { (USD/ha }\end{array}$} \\
\hline & & & Amount & $\begin{array}{c}\text { Value } \\
\text { (USD/ha) }\end{array}$ & Amount & $\begin{array}{c}\text { Value } \\
\text { (USD/ha) }\end{array}$ & \\
\hline \multicolumn{8}{|c|}{ I. Expenses } \\
\hline \multicolumn{8}{|c|}{ A. Agricultural Inputs } \\
\hline 1 & Seed (kg/ha) & 6.00 & 30.00 & 180.00 & 30.00 & 180.00 & 18.00 \\
\hline \multirow[t]{2}{*}{2} & Fertilizer & & & & & & \\
\hline & Sub Total (USD/ha) & & & 303.60 & & 303.60 & 248.40 \\
\hline \multirow[t]{2}{*}{3} & Herbicide & & & & & & \\
\hline & Sub Total (USD/ha) & & & 11.71 & & 18.67 & 4.75 \\
\hline \multirow[t]{2}{*}{4} & Pesticide & & & & & & \\
\hline & Sub Total (USD/ha) & & & 68.08 & & 68.08 & 48.08 \\
\hline & B. Labor & & & 379.27 & & 394.28 & 479.89 \\
\hline \multicolumn{8}{|c|}{ C. Fixed Cost } \\
\hline & Sub Total & & & 326.00 & & 326.00 & 212.00 \\
\hline & & & & 1268.67 & & 1290.64 & 1011.13 \\
\hline \multicolumn{2}{|r|}{ II. On-Farm Income } & & & & & & \\
\hline 1 & Yield (wet grain (ton/ha) & & 9.78 & & 9.28 & & 5.56 \\
\hline 2 & Price (USD/ton wet grain) & 275.86 & & & & & \\
\hline 3 & Gross Income (USD/ha) & & & 2697.91 & & 2559.98 & 1533.78 \\
\hline \multirow[t]{6}{*}{4} & Net Income (USD/ha) & & & 1429.24 & & 1269.34 & 522.65 \\
\hline & R/C Ratio & & & 2.13 & & 1.98 & 1.52 \\
\hline & B/C Ratio & & & 1.13 & & 0.98 & 0.52 \\
\hline & MBCR & & & & & & \\
\hline & a. CSI vs FP & & & 4.52 & & & \\
\hline & b. IIS vs FP & & & & & 3.67 & \\
\hline
\end{tabular}

Appendix3. Sensitivity analysis output of large scale full mechanized rice farming, 2017. Production fell by $20 \%$, but grain prices and production costs remain the same

\begin{tabular}{|c|c|c|c|c|c|c|c|}
\hline No & Description & $\begin{array}{c}\text { Unit price } \\
\text { (USD/unit) }\end{array}$ & \multicolumn{2}{c|}{$\begin{array}{c}\text { Continuous } \\
\text { Submerge } \\
\text { Irrigation System }\end{array}$} & \multicolumn{2}{|c|}{$\begin{array}{c}\text { Intermittent } \\
\text { Irrigation } \\
\text { System }\end{array}$} & $\begin{array}{c}\text { Farmer } \\
\text { Practices } \\
\text { (USD/ha) }\end{array}$ \\
\cline { 5 - 6 } & & Amount & $\begin{array}{c}\text { Value } \\
\text { (USD/ha) }\end{array}$ & Amount & $\begin{array}{c}\text { Value } \\
\text { (USD/ha) }\end{array}$ & \\
\hline & I. Expenses & & & & & & \\
\hline A. Agricultural Inputs & & & & & & \\
\hline 1 & Seed (kg/ha) & 5.00 & 30.00 & 150.00 & 30.00 & 150.00 & 15.00 \\
\hline 2 & Fertilizer & & & & & & \\
\hline & Sub Total (USD/ha) & & & 253.00 & & 253.00 & 207.00 \\
\hline 3 & Herbicide & & & & & & \\
\hline & Sub Total (USD/ha) & & & 9.76 & & 15.56 & 3.96 \\
\hline 4 & Pesticide & & & & & & \\
\hline & Sub Total (USD/ha) & & & 56.74 & & 56.74 & 40.07 \\
\hline & B. Labor & & & 316.06 & & 328.57 & 399.91 \\
\hline & C. Fixed Cost & & & & & & \\
\hline & Sub Total & & & 271.67 & & 271.67 & 176.67 \\
\hline & Total Cost & & & 1057.23 & & 1075.54 & 842.61 \\
\hline & II. On-Farm Income & & & & & & \\
\hline 1 & Yield (wet grain (ton/ha) & & 7.82 & & 7.42 & & 4.45 \\
\hline
\end{tabular}


Integrated Weed Management for Large Scale Direct Seeding Hybrid Rice Cultivation at Irrigated Land in Indonesia

\begin{tabular}{|c|c|c|c|c|c|c|c|}
\hline 2 & Price (USD/ton wet grain) & 275.86 & & & & & \\
\hline 3 & Gross Income (USD/ha) & & & 2158.33 & & 2047.98 & 1227.03 \\
\hline 4 & Net Income (USD/ha) & & & 1101.10 & & 972.45 & 384.42 \\
\hline & R/C Ratio & & & 2.04 & & 1.90 & 1.46 \\
\hline & B/C Ratio & & & 1.04 & & 0.90 & 0.46 \\
\hline & MBCR & & & & & & \\
\hline & a. CSI vs FP & & & 4.34 & & & \\
\hline & b. IIS vs FP & & & & & 3.52 & \\
\hline
\end{tabular}

Appendix4. Sensitivity Analysis output of large scale full mechanized rice farming, 2017. Production decreases by $20 \%$ and production costs increase by $20 \%$ which includes the cost of production facilities, labor and other costs

\begin{tabular}{|c|c|c|c|c|c|c|c|}
\hline \multirow[t]{2}{*}{ No } & \multirow[t]{2}{*}{ Description } & \multirow[t]{2}{*}{$\begin{array}{l}\text { Unit price } \\
\text { (USD/unit) }\end{array}$} & \multicolumn{2}{|c|}{$\begin{array}{c}\text { Continuous } \\
\text { Submerge } \\
\text { Irrigation System }\end{array}$} & \multicolumn{2}{|c|}{$\begin{array}{l}\text { Intermittent } \\
\text { Irrigation } \\
\text { System }\end{array}$} & \multirow[t]{2}{*}{$\begin{array}{c}\text { Farmer } \\
\text { Practices } \\
\text { (USD/ha) }\end{array}$} \\
\hline & & & Amount & $\begin{array}{c}\text { Value } \\
\text { (USD/ha) }\end{array}$ & Amount & $\begin{array}{c}\text { Value } \\
\text { (USD/ha) }\end{array}$ & \\
\hline \multicolumn{8}{|c|}{ I. Expenses } \\
\hline \multicolumn{8}{|c|}{ A. Agricultural Inputs } \\
\hline 1 & Seed $(\mathrm{kg} / \mathrm{ha})$ & 6.00 & 30.00 & 180.00 & 30.00 & 180.00 & 18.00 \\
\hline \multirow[t]{2}{*}{2} & Fertilizer & & & & & & \\
\hline & Sub Total (USD/ha) & & & 303.60 & & 303.60 & 248.40 \\
\hline \multirow[t]{2}{*}{3} & Herbicide & & & & & & \\
\hline & Sub Total (USD/ha) & & & 11.71 & & 18.67 & 4.75 \\
\hline \multirow[t]{2}{*}{4} & Pesticide & & & & & & \\
\hline & Sub Total (USD/ha) & & & 68.08 & & 68.08 & 48.08 \\
\hline & B. Labor & & & 379.27 & & 394.28 & 479.89 \\
\hline \multicolumn{8}{|c|}{ C. Fixed Cost } \\
\hline & Sub Total & & & 326.00 & & 326.00 & 212.00 \\
\hline & Total Cost & & & 1268.67 & & 1290.64 & 1011.13 \\
\hline \multicolumn{8}{|c|}{ II. On-Farm Income } \\
\hline 1 & Yield (wet grain (ton/ha) & & 7.82 & & 7.42 & & 4.45 \\
\hline 2 & Price (USD/ton wet grain) & 275.86 & & & & & \\
\hline 3 & Gross Income (USD/ha) & & & 2158.33 & & 2047.98 & 1227.03 \\
\hline \multirow[t]{6}{*}{4} & Net Income (USD/ha) & & & 889.66 & & 757.34 & 384.42 \\
\hline & R/C Ratio & & & 1.70 & & 1.59 & 1.46 \\
\hline & B/C Ratio & & & 0.70 & & 0.59 & 0.46 \\
\hline & MBCR & & & & & & \\
\hline & a. CSI vs FP & & & 2.19 & & & \\
\hline & b. IIS vs FP & & & & & 1.83 & \\
\hline
\end{tabular}

Citation: M. O. Adnyana, et.al, "Integrated Weed Management for Large Scale Direct Seeding Hybrid Rice Cultivation at Irrigated Land in Indonesia” International Journal of Research Studies in Agricultural Sciences (IJRSAS), 2019; 5(9), pp. 14-26, http://dx.doi.org/10.20431/2454-6224.0509003

Copyright: () 2019 Authors. This is an open-access article distributed under the terms of the Creative Commons Attribution License, which permits unrestricted use, distribution, and reproduction in any medium, provided the original author and source are credited. 